\title{
Evolutionary Perspectives on Myrmecophily in Ladybirds
}

\author{
Amélie Vantaux, ${ }^{1}$ Olivier Roux, ${ }^{2}$ Alexandra Magro, ${ }^{3,4}$ and Jérôme Orivel $^{5}$ \\ ${ }^{1}$ Entomology Laboratory, Zoological Institute, Catholic University of Leuven, Naamsestraat 59, Box 2466, 3000 Leuven, Belgium \\ ${ }^{2}$ Institut de Recherche pour le Développement, UMR MiVEGEC-Maladies Infectieuses et Vecteurs Écologie, Génétique, \\ Évolution et Contrôle, Antenne de Bobo-Dioulasso, 01 BP 171, Bobo Dioulasso 01, Burkina Faso \\ ${ }^{3}$ CNRS, UMR EDB-Evolution et Diversité Biologique, 118 Route de Narbonne, 31062 Toulouse, France \\ ${ }^{4}$ ENFA, UMR EDB-Evolution et Diversité Biologique, Université de Toulouse, 2 Route de Narbonne, \\ 31320 Castanet Tolosan, France \\ ${ }^{5}$ CNRS, UMR EcoFoG-Ecologie des Forêts de Guyane, Campus Agronomique, BP 316, 97379 Kourou Cedex, France
}

Correspondence should be addressed to Amélie Vantaux, amelie.vantaux@gmail.com

Received 4 October 2011; Accepted 4 December 2011

Academic Editor: Volker Witte

Copyright ( $\odot 2012$ Amélie Vantaux et al. This is an open access article distributed under the Creative Commons Attribution License, which permits unrestricted use, distribution, and reproduction in any medium, provided the original work is properly cited.

Myrmecophiles are species that usually have developed specialized traits to cope with the aggressiveness of ants enabling them to live in their vicinity. Many coccinellid species are predators of Hemiptera; the latter is also often protected by ants. Therefore these ladybirds frequently interact with ants, and some species have become myrmecophilous. In this paper, we aim to provide an overview of the evolution of myrmecophilous traits in ladybirds. We then discuss the costs and benefits of myrmecophily and the dietary shift to myrmecophagy observed in a few species.

\section{Introduction}

Ants represent a highly ecologically successful and most often dominant group of insects. Their predominance in almost all terrestrial ecosystems leads them to interact with many other organisms. One of the best-known examples of such interaction is their mutualism with Hemiptera. Ants protect the sap-feeding insects, and in return they benefit from the honeydew provided by the Hemiptera [1-3]. Honeydew is rich in carbohydrates and in some amino acids, which are attractive and nutritionally valuable for ants [4-7]. Additionally, the ants sometimes use aphids as a source of protein by consuming them [8-11]. Aside from protecting the Hemiptera, ants may also reduce their risk of getting fungal infections via hygienic behaviors [12-14], reduce indirect competition with untended Hemiptera [15], and they can even transport the Hemiptera to suitable feeding sites when a host plant's quality deteriorates [16]. Nevertheless, the main benefit for the Hemiptera when tended by ants is the protection the ants provide from natural enemies $[1,3,13,17-21]$. Untended colonies experience higher predation and parasitism rates. The colonies of the aphid Tuberculatus quercicola
(Matsumura), for example, had lower survival rates when ants were excluded [17], and the black cherry aphid Myzus cerasi (Fabricius) reached higher densities of individuals on trees with ants than on those without ants [18]. As a result of the protection they provide to Hemiptera, ants are in competition with predators such as ladybirds and syrphid larvae as well as parasitoids.

Ladybird species are well known for their aphido- and coccidophagy, which have popularized them as biocontrol agents in agricultural systems and private gardens. They exhibit, however, a large trophic diversity from mycophagous and phytophagous to predatory species. The latter species mainly eat coccids or aphids and, also to some extent, aleyrodes, psyllids, chrysomelids, and mites, although coccidophagy is considered more primitive than aphidophagy [22, 23]. The fact that many ladybird species prey on Hemiptera brings them into frequent contact with ants. Some of them use behavioral, physical, and chemical characteristics to cope with these aggressive competitors. Species found living regularly or only with ants are called "myrmecophiles" (from the Greek words for ants, "myrmex", and loving, "philos"). Their interactions span from facultative and diffuse relationships, 
which in ladybirds stems from their general defensive traits, to more obligate and integrated interactions which rely on specific adaptations. In this paper, we aim to provide an overview of the evolution of myrmecophilous traits in ladybirds [22-24]. We then discuss the costs and benefits of such specialization on ant-tended Hemiptera and the dietary shift to myrmecophagy demonstrated in a few species.

\section{Diversity and Biology of Myrmecophilous Species}

The Coccinellidae family consists of seven subfamilies [25] among which five include myrmecophilous species: Scymninae, Ortaliinae, Chilocorinae, Coccinellinae, and Coccidulinae [26-31] (Table 1). Interestingly, only one myrmecophilous species has been recorded to date in each of the three subfamilies Ortaliinae, Chilocorinae, and Coccinellinae and two in the subfamily Coccidulinae whereas there are eight species from the Scymninae subfamily belonging to four different tribes: one species from the Diomini tribe, two species from the Hyperaspidini and Brachiacanthadini tribes, and three species from the Scymnini tribe. Therefore, myrmecophilous species seem to be more strongly represented at the base of the phylogenetic tree [22-24]. Some myrmecophilous species have evolved more obligate relationships with ants and use chemical mimicry (i.e., the passive or active acquisition of a chemical signature by the myrmecophile allowing acceptance by the host) to evade ant aggressiveness. This adaptive trait has appeared in two different subfamilies with mimicry of the ant brood in the Scymninae $[28,32]$ and mimicry of the aphid prey in the Chilocorinae [33]. All of these characteristics and their distribution in the phylogeny show that myrmecophily appeared independently several times during the evolution of ladybirds [22-24], even in the case of the dietary shift to myrmecophagy which appeared both in the Scymninae [27, 28] and the Ortaliinae [34].

\subsection{General Defensive Traits}

2.1.1. Physical Traits. Many ladybird species, though not strictly myrmecophilous, encounter ants and show variation in their sensitivity to ant aggressiveness or to their venom [35]. Adults can, for example, hold the body tightly pressed against the plant surface when attacked by ants. Some species can completely conceal their legs under the body when cowering, such as individuals from the Chilocorinae subfamily, so that ants cannot seize any appendages which usually causes ant aggression to quickly cease $[33,35]$. Moreover, ladybirds use reflex bleeding as a general defense mechanism against their natural enemies. It has a mechanical protective effect since, as the haemolymph coagulates, it becomes more viscous and sticky, impeding the ants' movements [36].

Adult ladybirds are rather well protected by their sclerotized elytrae, while their larvae and pupae have soft bodies that are more sensitive to ant bites. The pupae are often protected by the larval skin shielding them and sometimes by their ability to use reflex bleeding [36] or by a dense covering of hair [33]. In some species, the pupae are also able to move up and down in response to a tactile stimulus [37], which could deter ant attacks. Many ladybird larvae have a waxy covering protecting them from their natural enemies, including ants [38]. When ants try to attack the larvae, their mandibles become covered by the covering's sticky filaments, and this usually causes them to stop and start grooming themselves. The two myrmecophilous species, Scymnus nigrinus (Kugelann) and S. interruptus (Goeze), are able to prey on ant-tended aphid colonies and to better survive predator attacks thanks to their waxy covering [30]. Myrmecophilous Brachiacantha quadripunctata (Melsheimer) and B. ursina (Fabricius) even get inside the ants' nest where they feed on ant-tended coccids and adelgids (Hemiptera, Aldegidae) [39, 40]. The waxy filaments also allow the myrmecophilous ladybird Azya orbigera (Mulsant) to feed on coccids tended by Azyeca instabilis (F. Smith) [29], and the larvae of the ladybird Ortalia pallens (Mulsant) to feed on Pheidole punctulata (Mayr) workers [34]. However, this waxy coating does not always provide an efficient protection as Pheidole megacephala (Fabricius) ants prey on Cryptolaemus montrouzieri (Mulsant) and A. orbigera ladybird larvae since they are able to remove their protective coating [19].

Some ladybird larvae that are devoid of a waxy covering, such as Diomus thoracicus (Fabricius) [28], Platynaspis luteorubra (Goeze) [33], and Scymnodes bellus (Blackburn) [27], show a convergent adaptation to ants in their general morphology: they are all ovate and flat with expanded marginal setae and short, stout legs. This body shape, with few exposed extremities, could be considered a protective type as has been found in other myrmecophilous Coleoptera [41].

2.1.2. Behavioural Traits. In myrmecophilous species, the larvae tend to move slowly and inconspicuously, as has been observed for Coccinella magnifica (Redtenbacher), P. luteorubra, and B. quadripunctata [33, 40, 42]. The comparison between the myrmecophilous species $C$. magnifica and its close nonmyrmecophilous relative C. septempunctata (Linnaeus) has shown that $C$. magnifica uses physical, behavioral, and chemical defenses adapted from the general defenses observed in Coccinellidae [42, 43]. No novel behavior or development of specific traits have been observed in C. magnifica [43]. One way for C. magnifica larvae to limit ant aggressiveness is to minimize the time spent on an aphid colony and thus the chance of encountering ants; for example, the larvae frequently pick up and carry their prey away from the colony before consuming it [42]. The fact that the nonmyrmecophilous $C$. septempunctata is also sometimes observed near ant-tended aphid colonies, especially at the end of the colonies' cycle when aphid colonies become scarce, and that reciprocally C. magnifica has been observed preying on untended colonies, suggests that the scarcity of prey may have been a selective pressure in the evolution of myrmecophily $[43,44]$. Indeed, during prey shortages, the limited availability of untended colonies might have forced ladybirds to prey on ant-tended colonies, opening the path to developing a tolerance towards ant aggressiveness. However, the myrmecophily of C. magnifica ladybirds has not been observed throughout its European habitat, suggesting that 
TABLE 1: Taxonomy and some biological characteristics of myrmecophilous ladybirds. Facultatively myrmecophilous species and species for which no reliable information is available are not included.

\begin{tabular}{|c|c|c|c|c|}
\hline Taxon & Ant associate & Larval diet & Myrmecophilous traits & References \\
\hline \multicolumn{5}{|l|}{ Chilocorinae } \\
\hline Platynaspis luteorubra & $\begin{array}{c}\text { Lasius niger, Myrmica rugulosa, } \\
\text { Tetramorium caepsicum }\end{array}$ & Ant-tended aphids & $\begin{array}{l}\text { Behavior, prey odor mimicry, } \\
\text { flat body, marginal setae, short } \\
\text { and stout legs }\end{array}$ & {$[33]$} \\
\hline \multicolumn{5}{|l|}{ Coccinellinae } \\
\hline Coccinella magnifica & Formica rufa & Ant-tended aphids & Behavior, chemical deterrent & {$[42,43]$} \\
\hline \multicolumn{5}{|l|}{ Coccidulinae } \\
\hline Azya orbigera & Azteca instabilis & Ant-tended coccids & Waxy covering & [29] \\
\hline Bucolus fourneti & Unknown & Ant workers & Waxy covering & {$[31]$} \\
\hline \multicolumn{5}{|l|}{ Ortalinae } \\
\hline Ortalia pallens & Pheidole punctulata & Ant workers & Waxy covering & {$[34]$} \\
\hline \multicolumn{5}{|l|}{ Scymninae } \\
\hline $\begin{array}{l}\text { Brachiacantha } \\
\text { quadripunctata }\end{array}$ & $\begin{array}{l}\text { Lasius umbratus, } \\
\text { Formica subpolita }\end{array}$ & $\begin{array}{l}\text { Ant-tended aphids and } \\
\text { adelgids }\end{array}$ & Behavior, and Waxy covering & {$[40]$} \\
\hline Brachiacantha ursina & Lasius sp. & $\begin{array}{l}\text { Ant-tended aphids and } \\
\text { adelgids }\end{array}$ & Waxy covering & {$[39]$} \\
\hline Hyperaspis reppensis & Tapinoma nigerrimum & $\begin{array}{l}\text { Apparently ant-tended } \\
\text { fulgorids }\end{array}$ & Body oval, and waxy covering & {$[60]$} \\
\hline Scymnodes bellus & Iridomyrmex sp. & Ant workers & $\begin{array}{c}\text { Flat body, marginal setae, short } \\
\text { and stout legs }\end{array}$ & {$[27]$} \\
\hline Scymnus interruptus & Lasius niger & Ant-tended aphids & Waxy covering & {$[30]$} \\
\hline Scymnus nigrinus & Formica polyctena & Ant-tended aphids & Waxy covering & {$[30]$} \\
\hline Diomus thoracicus & Wasmannia auropunctata & Ant brood & $\begin{array}{c}\text { Prey odor mimicry, flat body, } \\
\text { marginal setae, short and stout } \\
\text { legs }\end{array}$ & {$[28]$} \\
\hline Thalassa saginata & Dolichoderus bidens & Unknown & Ant mimicry & {$[32]$} \\
\hline
\end{tabular}

myrmecophily might be facultative or limited to some populations [45]. Concerning oviposition, two strategies have been observed. The eggs can be laid close to untended aphid colonies on which the emerging larvae can feed such as in C. magnifica [42], or females may try to oviposit directly in the Hemiptera colony despite possible ant aggressiveness. In the case of A. orbigera, females oviposit in the coccid colonies and lay the eggs under scale exuvia or carcasses to protect them from predation [46].

2.1.3. Chemical Traits. In addition to its mechanical impediment of ant movement, the haemolymph released during a reflex bleeding event often has a repellent effect due to the presence of alkaloids [47]. The alkaloids are synthesized by the ladybirds and seem to originate from fatty acids, as has been shown for the biosynthesis of coccinelline in $C$. septempunctata fat bodies [48]. Furthermore, their presence in eggs also provides them with a chemical protection that deters predators [47]. They could also act as an ant repellent but this remains to be demonstrated. The extremely repellent effect of the myrmecophilous ladybird C. magnifica has been suggested, but it has not been demonstrated yet $[42,43]$. Finally the waxy coating might also possess chemical properties helping to attenuate ant aggressiveness as it does for Scymnus louisianae (Chapin) [49].
2.2. Chemical Adaptation. Some myrmecophilous species employ a chemical strategy using a specific chemical signature on the cuticle $[28,32,33]$. They rely on a specific cuticular profile which can be obtained through passive or active acquisition [50] and results in the chemical mimicry of its prey odour, such as in P. luteorubra [33], or of the ant's brood in Thalassa saginata (Mulsant) [32] and D. thoracicus [28]. Thus, chemical mimicry helps some ladybirds to decrease ant aggressiveness, as in the case of $P$. luteorubra larvae, and even to disguise themselves as nestmates as in the case of $T$. saginata and $D$. thoracicus. Interestingly, chemical mimicry probably results from an adaptation as opposed to a preexisting trait, and it has only been observed in larvae thus far. Indeed, we would expect a preexisting trait to be observed in adults too, as it would help them to get the same benefits as their larvae, in particular avoiding ant aggressiveness at emergence. This adaptation might not be necessary in adults since they are protected by their hard elytrae and can readily fly away from the aphid colony in the case of P. luteorubra or even occupy a different niche as in the two nest-integrated ladybird larvae.

\section{Why Specialize on Ant-Tended Hemipteran Colonies?}

Since myrmecophilous interactions vary from facultative to obligate, the extent of the associated costs and benefits varies 
accordingly with the most integrated species having the highest costs but also the highest benefits.

3.1. Benefits. The first and most obvious benefit of being able to prey on ant-tended Hemiptera is gaining access to better food sources $[19,20,26,44]$. Indeed, ant-tended hemipteran colonies are usually larger, have a longer lifespan, and thus persist longer in late summer in temperate regions than untended colonies. For P. luteorubra, better foraging success was measured in ant-tended colonies and resulted in a higher adult weight, which is likely to positively influence adult fitness and survival [33]. This better foraging success has been explained by a decrease in the defensive behavior of aphids and a shorter searching distance in ant-tended colonies [33].

A second and important benefit of myrmecophily may arise from the access it provides to an enemy-free space. Ants limit interspecific and intraguild competition as well as access to the parasitoids and predators of ladybirds [29, 30, $33,51,52]$. The competitors of S. interruptus and S. nigrinus, for example, have been noted as being less present on anttended colonies [30]. Moreover, the presence of ants reduced larval parasitism by Homalotylus platynaspidis (Hoffer) (Hymenoptera, Chalcidoidea) in P. luteorubra [33], and the aggressive behaviour of $A$. instabilis disturbed the oviposition behavior of H. shuvakhinae (Trjapitzin), the most common parasitoid of A. orbigera [29]. Nonetheless, the observed decreases in parasitism rates do not always directly result from ant protection. C. magnifica larvae are less parasitized by the parasitoid Dinocampus coccinellae (Schrank) than the larvae of its close nonmyrmecophilous relative C. septempunctata found in the same area. Laboratory studies have shown that this is linked to the unsuccessful parasitism of $C$. magnifica and not to the presence of ants [53].

Ant parasitoids might also influence the interaction between ants and ladybirds. Phorid flies affect ant worker behavior by decreasing their activity [54-57]. During periods of low ant activity induced by the disturbance generated by phorid flies, A. orbigera adults can prey on the coccids at the same rate as in untended colonies and oviposit in the colony [46].

3.2. Costs. As discussed above, the specialization in preying on ant-tended Hemiptera depends mostly on the ability of ladybirds at all stages to be protected from ants. Ants aggressively protect the Hemiptera colonies, which disturbs ladybird foraging and can cause them to leave and stop exploiting a patch, and most importantly they can be injured or killed.

Another possible cost is that adaptation to ants would render the respective coccinellid species difficult to live without them. Myrmecophilous ladybirds could be poor competitors or poorly defended against predators and parasites as suggested by Majerus et al. [26]. The production of chemical defenses might be at the cost of other traits such as immunity or strong defenses against predators or parasites [26]. Furthermore, the association with ants is likely to decrease the habitat range available for the ladybird, especially for the most specific parasites specialized on one ant species.
Consequently, any reduction in the host habitat or abundance would directly affect the ladybirds' fitness and survival.

\section{Dietary Shift to Myrmecophagy}

Only four ladybird species larvae are currently known to feed on ants: Bucolus fourneti (Mulsant) [31], O. pallens that eats P. punctulata ants [34], S. bellus feeding on Iridomyrmex sp. [27], and D. thoracicus feeding on Wasmannia auropunctata (Roger) [28]. The first three species feed on ant workers outside the ant nest, relying on ant's foraging habits to get close to them. Thus, these species can stay relatively immobile and wait for prey to approach. In the case of D. thoracicus, the larvae are parasites that live inside the ant nest. The larvae are usually found in or near the brood pile where they have access to a constant food source. The integration of this species into the ant colonies relies on the chemical mimicry of its cuticular profile with the one of the ants' brood [28]. Only the adults leave the colonies early after emergence to avoid being attacked, as they do not share the same cuticular profile as the ants.

Such a dietary shift to myrmecophagy provides several important benefits. First, the ladybirds gain access to a food source available all year round and for many years since ant colonies are usually long-lived. Second, in the case of $D$. thoracicus, the larvae might be better protected from predators, parasitoids, and competitors lacking the adaptations needed to enter the ant nest. They may also benefit from a rather homeostatic environment in which temperature and humidity are rather constant and individuals are protected from climatic events.

The shift by ladybirds to myrmecophagy most probably followed the development of myrmecophily and as such bears the same costs, such as a more restricted niche due to specialization on ants. Nevertheless, these costs are largely balanced out by the access to a constant food resource both in time and quantity. This removes the constraints of resource limitation which are important in the evolution of habitat preferences and diet in predatory ladybirds [58]. Hemipteran colonies, and especially aphids, are a transient resource, and even if adult ladybirds can track them down by moving between patches, ladybird larvae are less mobile and limited to the colonies surrounding them. Therefore, the females of aphidophagous species tend to lay eggs early in the development of an aphid colony, known as the "egg window" [59], to ensure that their larvae have sufficient food. By feeding on ants, such limitation does not occur, which probably compensates for the costs of a myrmecophilous life style.

\section{Perspectives}

Despite being a highly species-rich group with around 6000 species described, the biology of most ladybird species, especially those found in the tropics, remains largely or even completely unknown. Only a few myrmecophilous species have been identified to date, but because most coccinellids encounter ants very frequently and often supplement their 
essential food sources with other food items (which might help in their being able to shift to new diet and habitat), it would not be surprising that many more myrmecophilous species still remain to be discovered. Among the seven subfamilies of Coccinellidae, myrmecophilous species have been identified in only five of them with, moreover, most of them concentrated in the Scymninae subfamily [26-30]. The predominance of myrmecophily in the Scymninae raises the question of the evolution of traits that promoted such interactions with ants. Gaining more knowledge on the biology of myrmecophilous ladybirds, especially the ones having shifted to myrmecophagy, would provide insights on the evolution of myrmecophily and myrmecophagy in this family.

The ladybird diet is usually similar in larvae and adults; nonetheless, ants attack adult $D$. thoracicus suggesting that they rely on a different food source than do the larvae. The biologies of adult $O$. pallens and S. bellus ladybirds are unknown as well. Unraveling the diet of all stages in these three species would shed light on the origin of the dietary shift to myrmecophagy. The adults might be adapted to preying on ant-tended Hemiptera colonies which would have favored a dietary shift in the larvae. It has also been hypothesized that the limited availability of prey at some point in time might have been a selective pressure in the evolution of myrmecophily in the case of $C$. magnifica [43, 44]. A similar constraint could apply to the tropical and subtropical myrmecophagous species with the advantage of a dietary shift to ants associated with a food source available all year round since there is no dormancy period. In temperate areas, ladybirds overwinter at the adult stage. Thus, one can hypothesize that the lifecycles of ladybirds and ants might not be synchronized enough to have permitted myrmecophagy to appear in these regions. Finally, another hypothesis might be that since both ladybird species from subfamilies rooted at the base of the phylogenetic tree and coccids are more abundant and diversified in the Southern hemisphere, there might be more opportunities for myrmecophily to arise in these areas, both from a larger number of possible interactions and a longer common evolutionary history.

\section{Financial Support}

Financial support was provided by the French Ministère de l'Ecologie et du Développement Durable_Programme Ecosystèmes Tropicaux and the Programme Convergence 20072013, Région Guyane from the European Community.

\section{Acknowledgments}

The authors would like to thank Andrea Yockey-Dejean for proofreading the paper. They are grateful to J. P. Lachaud for his invitation to contribute to this paper, to two reviewers for their useful comments on the paper, and to the Laboratoire Environnement de Petit Saut (HYDRECO) for logistical help during their fieldwork on Diomus thoracicus.

\section{References}

[1] M. J. Way, "Mutualism between ants and honeydew-producing Homoptera," Annual Review of Entomology, vol. 8, pp. 307344, 1963.
[2] B. Stadler and A. F. G. Dixon, "Ecology and evolution of aphidant interactions," Annual Review of Ecology, Evolution, and Systematics, vol. 36, pp. 345-372, 2005.

[3] B. Hölldobler and E. O. Wilson, The Ants, Springer, Berlin, Germany, 1990.

[4] M. K. Fischer, W. Völkl, R. Schopf, and K. H. Hoffmann, "Agespecific patterns in honeydew production and honeydew composition in the aphid Metopeurum fuscoviride: implications for ant-attendance," Journal of Insect Physiology, vol. 48, no. 3, pp. 319-326, 2002.

[5] J. Woodring, R. Wiedemann, M. K. Fischer, K. H. Hoffmann, and W. Völkl, "Honeydew amino acids in relation to sugars and their role in the establishment of ant-attendance hierarchy in eight species of aphids feeding on tansy (Tanacetum vulgare)," Physiological Entomology, vol. 29, no. 4, pp. 311-319, 2004.

[6] A. E. Douglas, "The nutritional physiology of aphids," in Advances in Insect Physiology, pp. 73-140, Academic Press, New York, NY, USA, 2003.

[7] J. L. Boevé and F. L. Wäckers, "Gustatory perception and metabolic utilization of sugars by Myrmica rubra ant workers," Oecologia, vol. 136, no. 4, pp. 508-514, 2003.

[8] A. J. Pontin, "Numbers and distyribution of subterranean aphids and their exploitation by ant Lasius flavus (Fabr.)," Ecological Entomology, vol. 3, pp. 203-207, 1978.

[9] J. Offenberg, "Balancing between mutualism and exploitation: the symbiotic interaction between Lasius ants and aphids," Behavioral Ecology and Sociobiology, vol. 49, no. 4, pp. 304310, 2001.

[10] H. Sakata, "How an ant decides to prey on or to attend aphids," Researches on Population Ecology, vol. 36, no. 1, pp. 45-51, 1994.

[11] H. Sakata, "Density-dependent predation of the ant Lasius niger (Hymenoptera: Formicidae) on two attended aphids Lachnus tropicalis and Myzocallis kuricola (Homoptera: Aphididae)," Researches on Population Ecology, vol. 37, no. 2, pp. 159-164, 1995.

[12] C. Nielsen, A. A. Agrawal, and A. E. Hajek, "Ants defend aphids against lethal disease," Biology Letters, vol. 6, no. 2, pp. 205208, 2010.

[13] C. J. Banks, "Effects of the ant Lasius niger (L.) on insects preying on small populations of Aphis fabae Scop. on bean plants," Annals of Applied Biology, vol. 50, pp. 669-679, 1962.

[14] K. Matsuura and T. Yashiro, "Aphid egg protection by ants: a novel aspect of the mutualism between the tree-feeding aphid Stomaphis hirukawai and its attendant ant Lasius productus," Naturwissenschaften, vol. 93, no. 10, pp. 506-510, 2006.

[15] M. Miñarro, G. Fernández-mata, and P. Medina, "Role of ants in structuring the aphid community on apple," Ecological Entomology, vol. 35, no. 2, pp. 206-215, 2010.

[16] M. J. Way, "Studies on the association of the ant Oecophylla longinoda (Latr.) (Formicidae) with the scale insect Saissetia zanzibarensis Williams (Coccidae)," Bulletin of Entomological Research, vol. 45, pp. 113-134, 1954.

[17] I. Yao, H. Shibao, and S. I. Akimoto, "Costs and benefits of ant attendance to the drepanosiphid aphid Tuberculatus quercicola," Oikos, vol. 89, no. 1, pp. 3-10, 2000.

[18] S. Stutz and M. H. Entling, "Effects of the landscape context on aphid-ant-predator interactions on cherry trees," Biological Control, vol. 57, no. 1, pp. 37-43, 2011.

[19] C. E. Bach, "Direct and indirect interactions between ants (Pheidole megacephala), scales (Coccus viridis) and plants (Pluchea indica)," Oecologia, vol. 87, no. 2, pp. 233-239, 1991. 
[20] L. M. Hanks and C. S. Sadof, "The effect of ants on nymphal survivorship of Coccus viridis (Homoptera, Coccidae)," Biotropica, vol. 22, pp. 210-213, 1990.

[21] T. Itioka and T. Inoue, "The role of predators and attendant ants in the regulation and persistence of a population of the citrus mealybug Pseudococcus citriculus in a Satsuma orange orchard," Applied Entomology and Zoology, vol. 31, no. 2, pp. 195-202, 1996.

[22] A. Magro, E. Lecompte, F. Magné, J. L. Hemptinne, and B. Crouau-Roy, "Phylogeny of ladybirds (Coleoptera: Coccinellidae): are the subfamilies monophyletic?" Molecular Phylogenetics and Evolution, vol. 54, no. 3, pp. 833-848, 2010.

[23] J. A. Giorgi, N. J. Vandenberg, J. V. McHugh et al., "The evolution of food preferences in Coccinellidae," Biological Control, vol. 51, no. 2, pp. 215-231, 2009.

[24] A. E. Seago, J. A. Giorgi, J. Li, and A. Ślipiński, "Phylogeny, classification and evolution of ladybird beetles (Coleoptera: Coccinellidae) based on simultaneous analysis of molecular and morphological data," Molecular Phylogenetics and Evolution, vol. 60, no. 1, pp. 137-151, 2011.

[25] I. Kovár, "Phylogeny," in Ecology of Coccinellidae, I. Hodek and A. Honek, Eds., pp. 19-31, Kluwer Academic Publishers, Dordrecht, The Netherlands, 1996.

[26] M. E. N. Majerus, J. J. Sloggett, J. F. Godeau, and J. L. Hemptinne, "Interactions between ants and aphidophagous and coccidophagous ladybirds," Population Ecology, vol. 49, no. 1, pp. 15-27, 2007.

[27] R. D. Pope and J. F. Lawrence, "A review of Scymnodes Blackburn, with the description of a new Australian species and its larva (Coleoptera: Coccinellidae)," Systematic Entomology, vol. 15, pp. 241-252, 1990.

[28] A. Vantaux, O. Roux, A. Magro et al., "Host-specific myrmecophily and myrmecophagy in the tropical coccinellid Diomus thoracicus in French Guiana," Biotropica, vol. 42, no. 5, pp. 622-629, 2010.

[29] H. Liere and I. Perfecto, "Cheating on a mutualism: indirect benefits of ant attendance to a coccidophagous coccinellid," Environmental Entomology, vol. 37, no. 1, pp. 143-149, 2008.

[30] W. Völkl and K. Vohland, "Wax covers in larvae of two Scymnus species: do they enhance coccinellid larval survival?" Oecologia, vol. 107, no. 4, pp. 498-503, 1996.

[31] A. Ślipiński, Australian Ladybird Beetles (Coleoptera: Coccinellidae) Their Biology and Classification, Australia Australian Biological Resources Study, Canberra, Australia, 2007.

[32] J. Orivel, P. Servigne, P. Cerdan, A. Dejean, and B. Corbara, "The ladybird Thalassa saginata, an obligatory myrmecophile of Dolichodeurs bidens ant colonies," Naturwissenschaften, vol. 91, no. 2, pp. 97-100, 2004.

[33] W. Volkl, "Behavioral and morphological adaptations of the coccinellid, Platynaspis luteorubra for exploiting ant-attended resources (Coleoptera: Coccinellidae)," Journal of Insect Behavior, vol. 8, no. 5, pp. 653-670, 1995.

[34] R. H. T. P. Harris, "A note on Ortalia pallens Muls," South African Journal of Science, vol. 17, pp. 170-171, 1921.

[35] C. J. Finlayson, A. V. Alyokhin, and E. W. Porter, "Interactions of native and non-native lady beetle species (Coleoptera: Coccinellidae) with aphid-tending ants in laboratory arenas," Environmental Entomology, vol. 38, no. 3, pp. 846-855, 2009.

[36] G. M. Happ and T. Eisner, "Hemorrhage in a coccinellid beetle and its repellent effect on ants," Science, vol. 134, no. 3475, pp. 329-331, 1961.

[37] M. E. N. Majerus, Ladybirds, Harper Collins, London, UK, 1994.
[38] R. D. Pope, "Wax production by coccinellid larvae (Coleoptera)," Systematic Entomology, vol. 4, pp. 171-196, 1979.

[39] J. B. Smith, "Ants' nests and their inhabitants," American Naturalist, vol. 20, pp. 679-687, 1886.

[40] W. M. Wheeler, "An ant-nest coccinellid (Brachyacantha quadripunctata Mels.)," Journal of the New York Entomological Society, vol. 19, pp. 169-174, 1911.

[41] S. F. Geiselhardt, K. Peschke, and P. Nagel, "A review of myrmecophily in ant nest beetles (Coleoptera: Carabidae: Paussinae): linking early observations with recent findings," Naturwissenschaften, vol. 94, no. 11, pp. 871-894, 2007.

[42] J. J. Sloggett and E. N. Majerus, "Adaptations of Coccinella magnifica, a myrmecophilous coccinellid to aggression by wood ants (Formica rufa group). II. Larval behaviour, and ladybird oviposition location," European Journal of Entomology, vol. 100, no. 3, pp. 337-344, 2003.

[43] J. J. Sloggett, R. A. Wood, and M. E. N. Majerus, "Adaptations of Coccinella magnifica redtenbacher, a myrmecophilous coccinellid, to aggression by wood ants (Formica rufa Group). I. Adult behavioral adaptation, its ecological context and evolution," Journal of Insect Behavior, vol. 11, no. 6, pp. 889-904, 1998.

[44] J. J. Sloggett and M. E. N. Majerus, "Aphid-mediated coexistence of ladybirds (Coleoptera: Coccinellidae) and the wood ant Formica rufa: seasonal effects, interspecific variability and the evolution of a coccinellid myrmecophile," Oikos, vol. 89, no. 2, pp. 345-359, 2000.

[45] J. J. Sloggett, W. Völkl, W. Schulze, J. H. G. V. D. Schulenburg, and E. N. Majerus, "The ant-associations and diet of the ladybird Coccinella magnifica (Coleoptera: Coccinellidae)," European Journal of Entomology, vol. 99, no. 4, pp. 565-569, 2002.

[46] H. Liere and A. Larsen, "Cascading trait-mediation: disruption of a trait-mediated mutualism by parasite-induced behavioral modification," Oikos, vol. 119, no. 9, pp. 1394-1400, 2010.

[47] J. M. Pasteels, "Chemical defence, offence and alliance in antsaphids-ladybirds relationships," Population Ecology, vol. 49, no. 1, pp. 5-14, 2007.

[48] P. Laurent, J. C. Braekman, D. Daloze, and J. Pasteels, "Biosynthesis of defensive compounds from beetles and ants," European Journal of Organic Chemistry, no. 15, pp. 2733-2743, 2003.

[49] E. G. Schwartzberg, K. F. Haynes, D. W. Johnson, and G. C. Brown, "Wax structures of Scymnus louisianae attenuate aggression from aphid-tending ants," Environmental Entomology, vol. 39, no. 4, pp. 1309-1314, 2010.

[50] A. Lenoir, P. D'Ettorre, C. Errard, and A. Hefetz, "Chemical ecology and social parasitism in ants," Annual Review of Entomology, vol. 46, pp. 573-599, 2001.

[51] D. C. Weber and J. G. Lundgren, "Assessing the trophic ecology of the Coccinellidae: their roles as predators and as prey," Biological Control, vol. 51, no. 2, pp. 199-214, 2009.

[52] S. Sato, A. F. G. Dixon, and H. Yasuda, "Effect of emigration on cannibalism and intraguild predation in aphidophagous ladybirds," Ecological Entomology, vol. 28, no. 5, pp. 628-633, 2003.

[53] J. J. Sloggett, K. M. Webberley, and M. E. N. Majerus, "Low parasitoid success on a myrmecophilous host is maintained in the absence of ants," Ecological Entomology, vol. 29, no. 1, pp. 123-127, 2004.

[54] S. M. Philpott, "Trait-mediated effects of parasitic phorid flies (Diptera: Phoridae) on ant (Hymenoptera: Formicidae) competition and resource access in coffee agro-ecosystems," Environmental Entomology, vol. 34, no. 5, pp. 1089-1094, 2005. 
[55] D. H. Feener, "Competition between ant species: outcome controlled by parasitic flies," Science, vol. 214, no. 4522, pp. 815-817, 1981.

[56] E. G. LeBrun and D. H. Feener, "Linked indirect effects in ant-phorid interactions: impacts on ant assemblage structure," Oecologia, vol. 133, no. 4, pp. 599-607, 2002.

[57] L. W. Morrison, E. A. Kawazoe, R. Guerra, and L. E. Gilbert, "Ecological interactions of Pseudacteon parasitoids and Solenopsis ant hosts: environmental correlates of activity and effects on competitive hierarchies," Ecological Entomology, vol. 25, no. 4, pp. 433-444, 2000.

[58] J. J. Sloggett and M. E. N. Majerus, "Habitat preferences and diet in the predatory Coccinellidae (Coleoptera): an evolutionary perspective," Biological Journal of the Linnean Society, vol. 70, no. 1, pp. 63-88, 2000.

[59] J. L. Hemptinne, A. F. G. Dixon, and J. Coffin, "Attack strategy of ladybird beetles (Coccinellidae): factors shaping their numerical response," Oecologia, vol. 90, no. 2, pp. 238-245, 1992.

[60] F. Silvestri, "Contribuzioni alla conoscenza dei Mirmecophili, I. Osservazioni su alcuni mirmecophili dei dintorni di Portici," Annuario del Museo Zoologico della Ricerche Università di Napoli, vol. 1, pp. 1-5, 1903. 

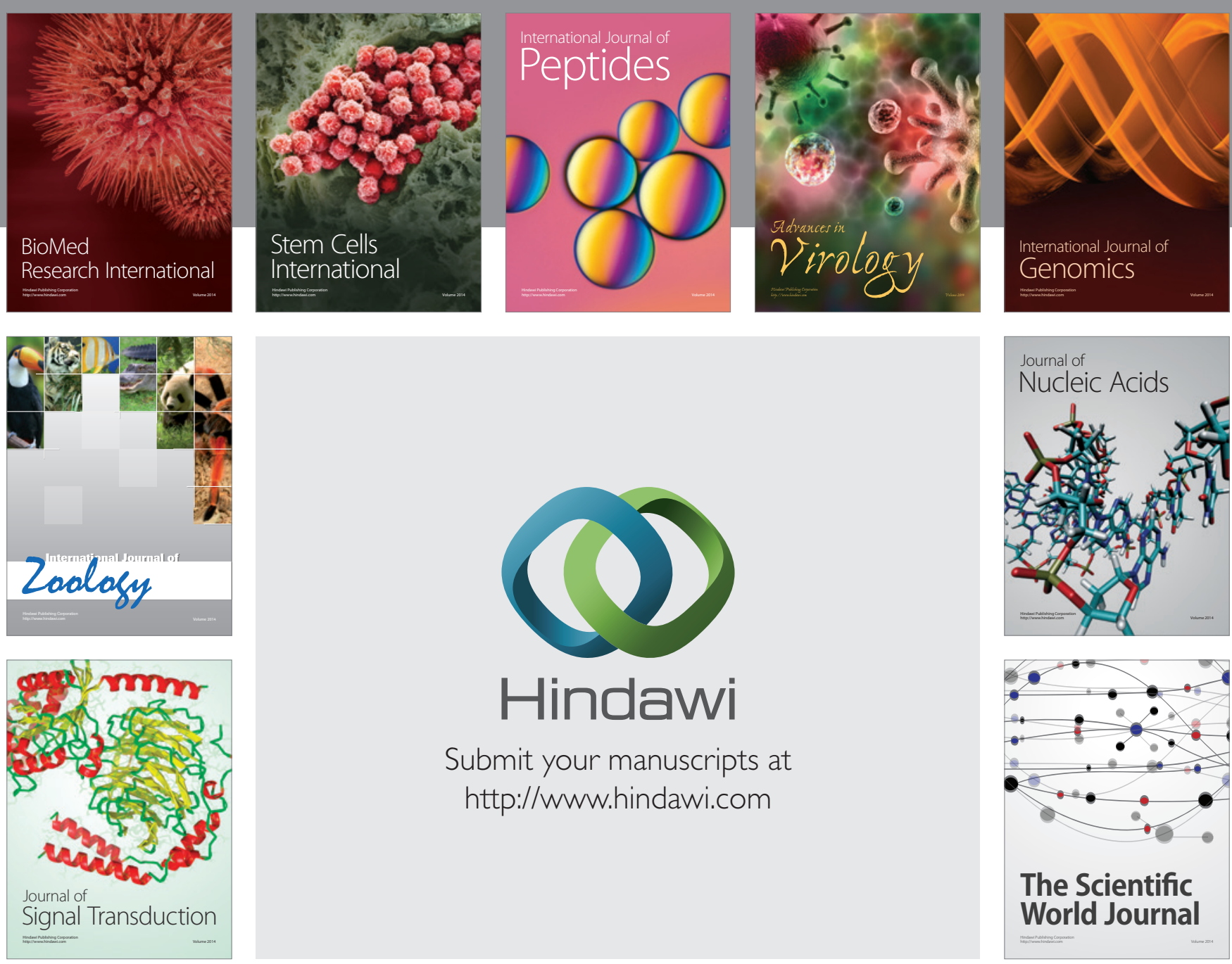

Submit your manuscripts at

http://www.hindawi.com
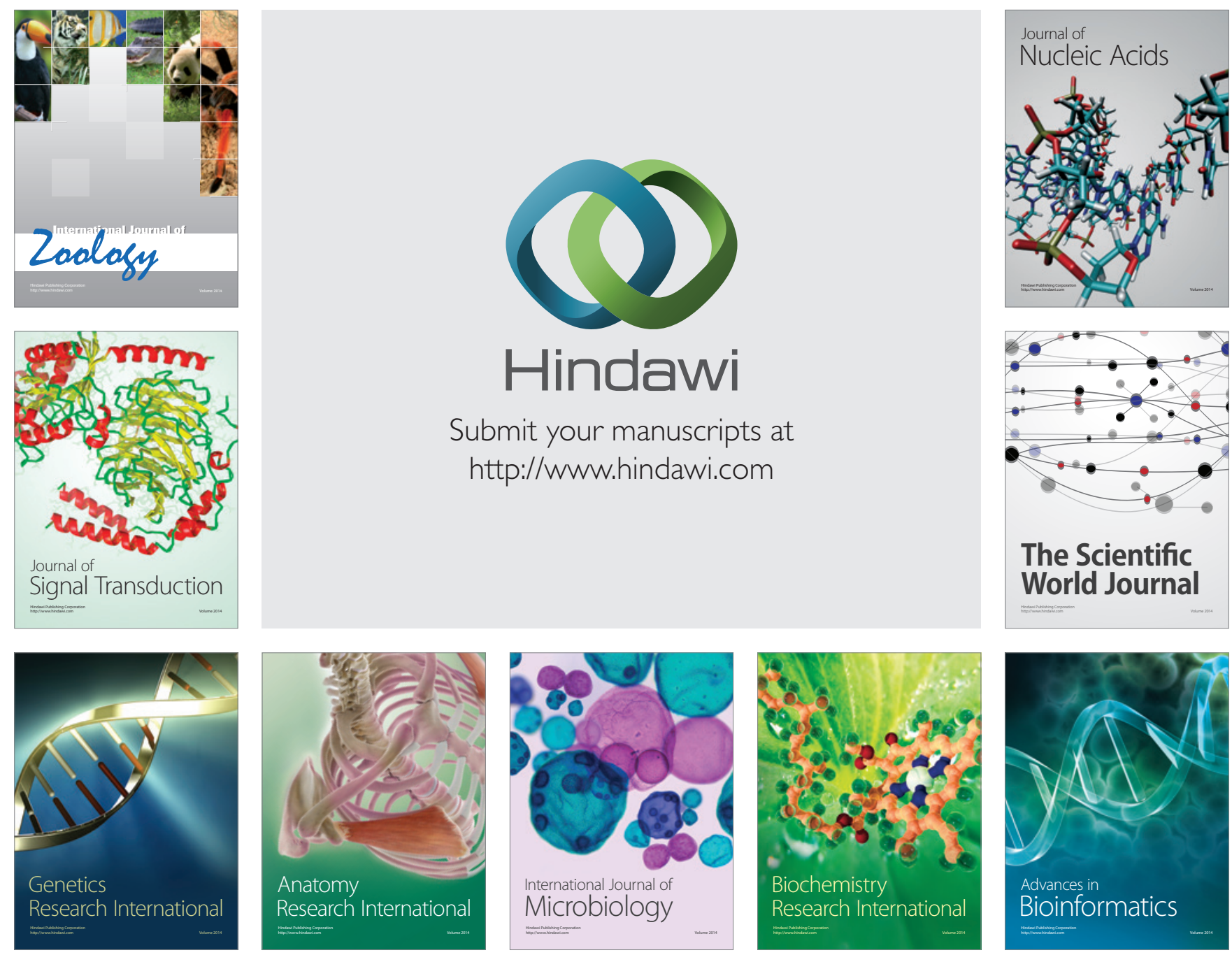

The Scientific World Journal
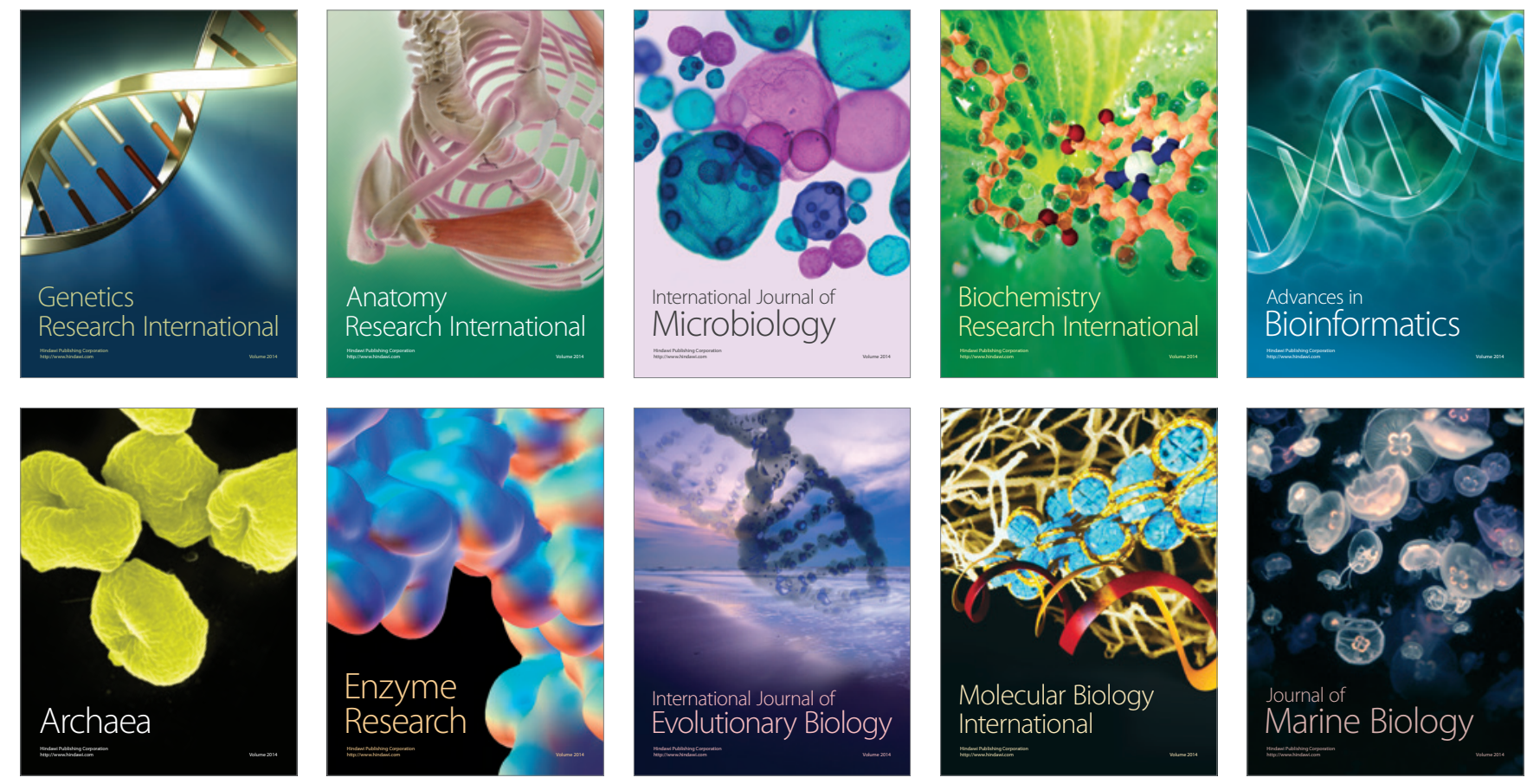